\title{
Effect of Rock-Sized Aggregates on Soil Compaction Results
}

\author{
Arinze, Emmanuel E. \\ Department Of Civil Engineering Michael Okpara University Of Agriculture Umudike
}

\begin{abstract}
In the construction of highway embankments, earth dams and many other engineering structures. It is recommended that three contractors must achieve a compacted field dry unit of 90\%-95\% of the maximum dry density. The values are often affected by varying percentages of large aggregate which consultants and contractors do not usually put into consideration. In this research work three methods of handling rock sized aggregates which include compacting the whole sample (method 1) compacting only samples passing through sieve No. $4(4.75 \mathrm{~mm})$ and (method 2) using rock correction equation. It is discovered that correction methods (methods 2 \& 3) are consistent when percentage passing through sieve No. 4 is greater than 30. It is recommended that the average values of the correction methods be used rather than depending on only one correction method.
\end{abstract}

Keywords: compaction, rock sized-aggregates, rock correction

\section{Introduction}

In the construction of highway embankments, earth dams and many other engineering structures, loose soils must be compacted to increase their dry density. Compaction increases the strength characteristics of soils thereby increasing the amount of undesirable settlement of structures and increases the stability of slope embankment (Braja M. D, 2005)

Compaction control for construction is mostly based on the requirement that the contractor meet a certain maximum dry density as obtained by standard test procedure such as ASTM 9698 or the American Association of State Highway and Transportation Officials (AASHTO) T99. As a result, laboratory specimens compacted to minimum specification is performed to assist in making decisions regarding the adequacy of the specification required for field compaction. Moreover, when field materials contain a significant percentage of large aggregate, laboratory compaction becomes challenging and the required compaction specification for a project is determined almost exclusively on an empirical basis in most specification for earthwork, one stipulation is that the contractor must achieve a compacted field dry unit weight of $90 \%$ to $95 \%$ of the maximum dry density determined in the laboratory by either the standard or modified proctor test. This specification is for relative compaction to which can be expressed as

$$
\mathrm{R}(\%)=\left[\frac{\rho_{\mathrm{d}(\text { field })}}{\rho_{\mathrm{d}(\max -\text { La b })}}\right] \times 100
$$

In the compaction of granular soil, specification can be written in terms of the required density $\mathrm{Dr}$ or compaction.

$$
\mathrm{D}_{\mathrm{r}}=\left[\frac{\rho_{\mathrm{d}(\text { field })}-\rho_{\mathrm{d}(\min )}}{\rho_{\mathrm{d}(\max )}-\rho_{\mathrm{d}(\min )}}\right]\left[\frac{\rho_{\mathrm{d}(\max )}}{\rho_{\mathrm{d}(\text { field })}}\right]
$$

Lee and Singh (1971) on observation of 47 soil samples, gave a relation between $R$ and $D_{r}{ }^{\text {for }}$ granular soils as

$$
\mathrm{R}=80+0.2 \mathrm{Dr}
$$

In this study, comparisons were made between different techniques used to obtain a reference maximum dry density for soils containing large aggregate. This reference dry density is often obtained using basically four methods. When the borrow pit material contains significant amounts of rock that is, material retained on the No 4 sieve, Reference value of maximum dry density is expected to include the effect of the rock. The rock can be accounted for in any of these ways.

1. Perform large-scale test using the entire rock fraction as it occurs in the field to get the maximum dry density (MDD) and optimum water content (OMC).

2. Perform small scale compaction test for which the material retained of sieve No. 4 is removed before compaction and replaced with an equal weight of No. $4(19 \mathrm{~mm})$ material [ASTM method D698, using a $15.24 \mathrm{~cm}$ mold or AASHTO T99, method c casing $10.16 \mathrm{~cm}$ mold]. This method is the scalp and replaces method.

3. Perform small scale compaction tests for which the material passing the sieve No. 4 is compacted in a $15.24 \mathrm{~cm}$ mold, but the plus No. 4 sieve material is discarded [e.g. ASTM D698, method plus $19 \mathrm{~mm}$ material is less than $10 \%$ by weight.

4. Perform compaction test on the minus 4 fraction content for the minus No 4. Material. With minus No 4. Values to obtain an estimate content of the field soil, for example ASTM procedure D4718, AASHTO 
procedure T224 or U.S Bureau of reclamation (USBR) procedure 5515 - 89. (Houston S. L. And Waish K. D. 1993).

\section{Materials and methods}

The materials used for the test were collected from three different points in Agu-Awka-Nibo road South- Eastern Nigeria. The properties of the soil collected are as follows

\begin{tabular}{cccc}
\hline & SOIL A & SOIL B & SOIL C \\
\hline Colour & Reddish Brown & Reddish Brown & Grey \\
\% retained on sieve No. 4 & $39 \%$ & $31 \%$ & $19 \%$ \\
Unit weight & 16.87 & 14.80 & 14.03 \\
Void ratio & 0.33 & 0.42 & 0.85 \\
Specific gravity & 2.56 & 2.61 & 2.64 \\
Natural Moisture content & 4.94 & 7.91 & 6.89
\end{tabular}

With respect to the values obtained methods 1,2 and 4 were used in the study. This implies that a compaction test were carried out for

i. $\quad$ Sample passing through sieve No. 4

ii. The whole sample

iii. In addition to this rock correction according to ASTM D4718 which states that

$\mathrm{D}=62.41\{(\mathrm{Pc} / \mathrm{Gm})+[62.4(1-\mathrm{Pc}) / \mathrm{Df})\}$

Where computed for each of the samples

Where $\mathrm{D}=$ maximum dry density of combined soil (Pcf)

$\mathrm{Pc}=$ percentage rock by weight (decimal); $\mathrm{Gm}=$ bulk specific gravity of rock $; \mathrm{df}=$ maximum dry density of finer material.

The results were as follows

\section{Results and Discussion}

WHOLE SAMPLE (method 1): a compaction test were conducted for the three sample A - C and the results and corresponding curve were shown in table $3.1-3.3$ and fig $3.1-3.3$ respectively.

SAMPLE A

\begin{tabular}{|l|l|l|l|}
\hline Weight of wet soil & Bulk density $\left(\mathrm{kg} / \mathrm{m}^{3}\right)$ & Moisture content $(\%)$ & Dry density $\left(\mathrm{kg} / \mathrm{m}^{3}\right)$ \\
\hline 1.80 & 1800 & 4.4 & 1724.1 \\
\hline 1.95 & 1950 & 9.5 & 1780.8 \\
\hline 2.15 & 2150 & 12.1 & 1917.9 \\
\hline 2.05 & 2050 & 17.1 & 1750.6 \\
\hline 2.05 & 2050 & 20.9 & 1695.6 \\
\hline
\end{tabular}

Table 3.1: Results of compaction test for sample a (whole sample)

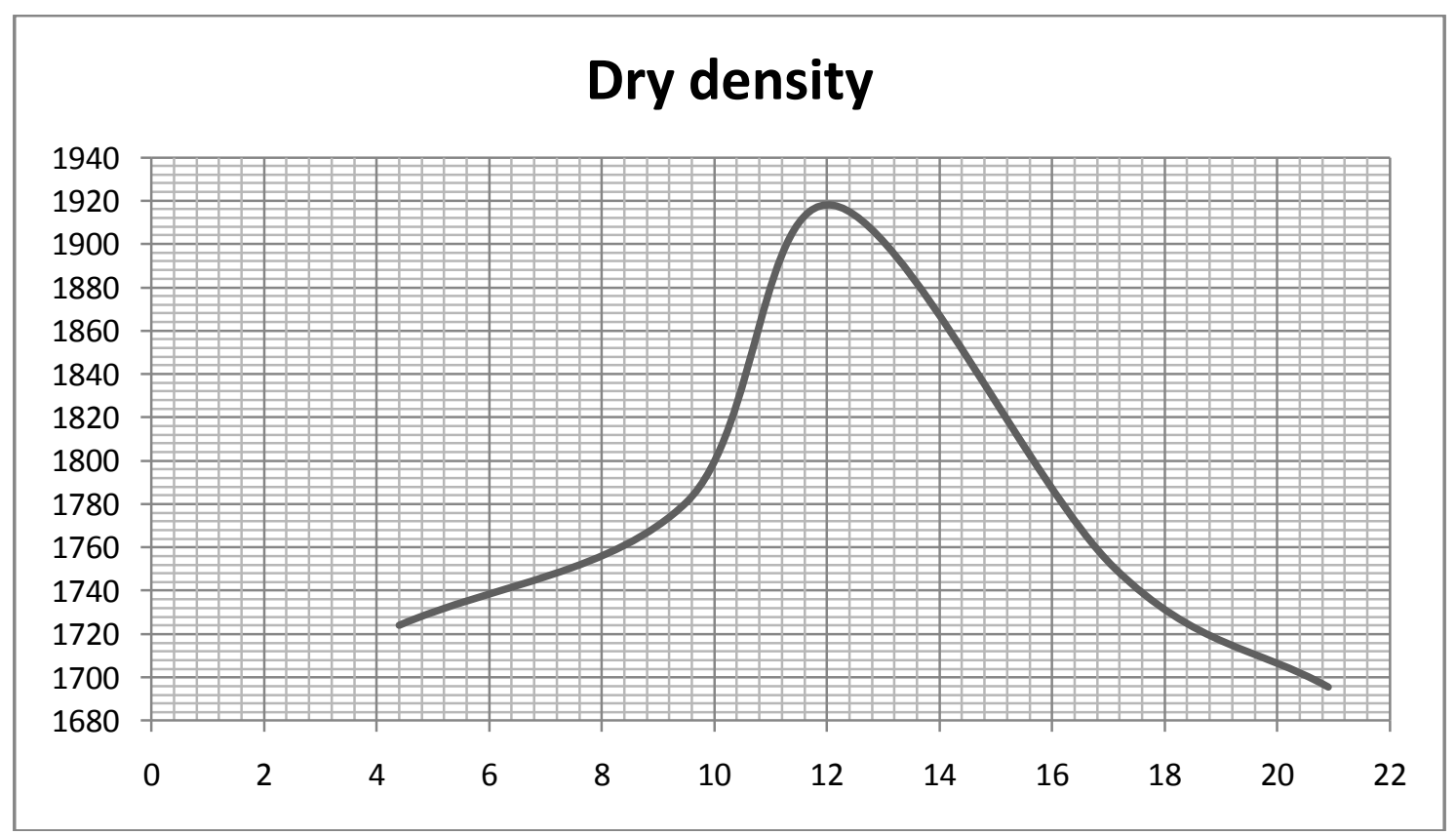

Fig 3.1: Compaction curve for sample A (whole sample) 


\section{SAMPLE B}

\begin{tabular}{|l|l|l|l|}
\hline Weight of wet soil & Bulk density $\left(\mathrm{kg} / \mathrm{m}^{3}\right)$ & Moisture content $(\%)$ & Dry density $\left(\mathrm{kg} / \mathrm{m}^{3}\right)$ \\
\hline 1.65 & 1650 & 5.5 & 1564.0 \\
\hline 1.80 & 1800 & 9.4 & 1645.3 \\
\hline 2.10 & 2100 & 12.8 & 1861.7 \\
\hline 2.00 & 2000 & 16.2 & 1721.2 \\
\hline 2.00 & 2000 & 20.3 & 1662.5 \\
\hline
\end{tabular}

Table 3.2: Results of compaction test for sample B (whole sample)

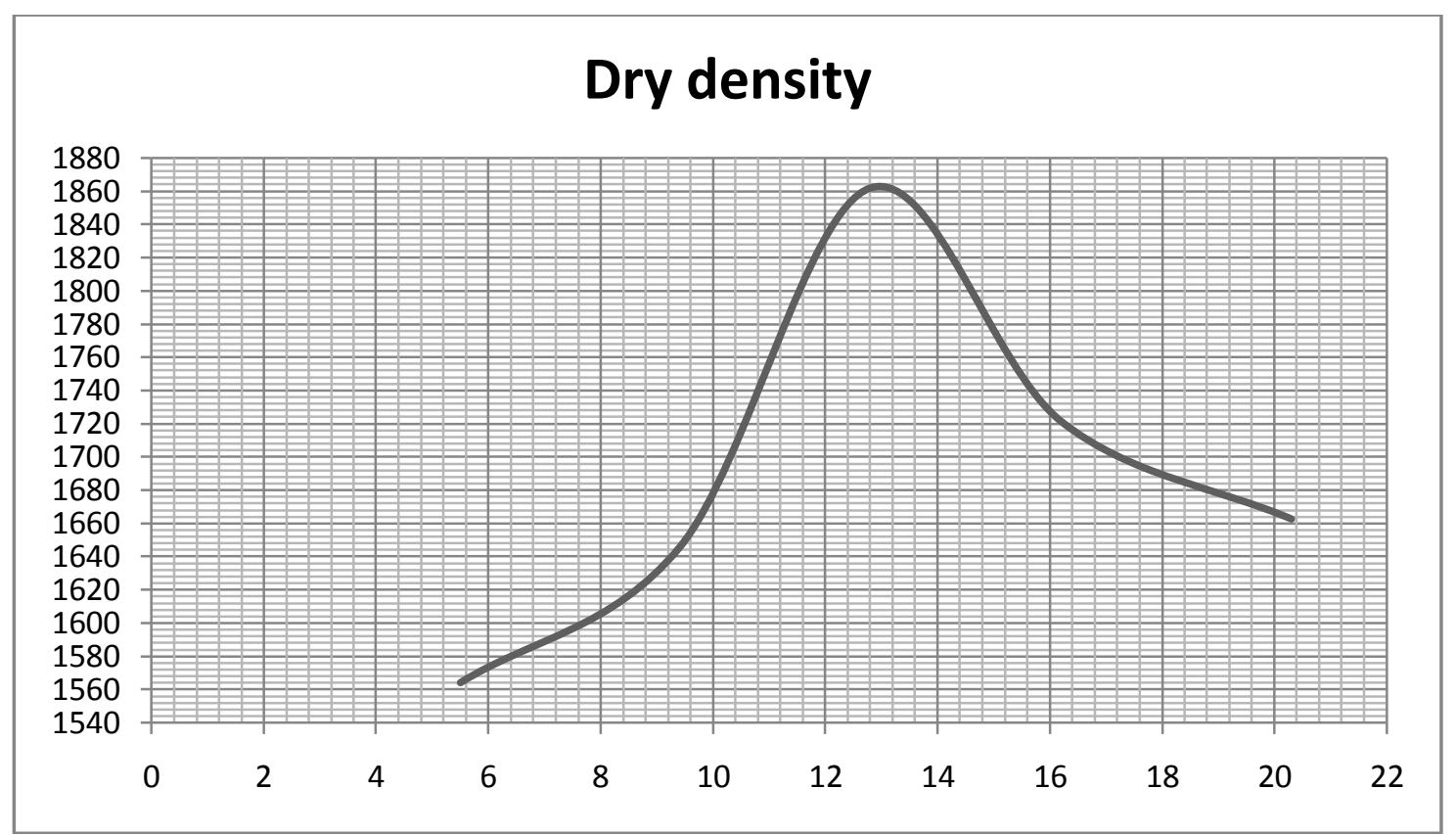

Fig 3.2: compaction curve for ample B (whole sample).

SAMPLE C

\begin{tabular}{|l|l|l|l|}
\hline Weight of wet soil & Bulk density $\left(\mathrm{kg} / \mathrm{m}^{3}\right)$ & Moisture content $(\%)$ & Dry density $\left(\mathrm{kg} / \mathrm{m}^{3}\right)$ \\
\hline 1.75 & 1855.2 & 8.4 & 1711.4 \\
\hline 2.00 & 2120.2 & 12.3 & 1888.0 \\
\hline 2.10 & 2226.2 & 16.6 & 1909.3 \\
\hline 2.00 & 2120.2 & 22.1 & 1736.4 \\
\hline 1.90 & 2014.2 & 23.2 & 1634.9 \\
\hline
\end{tabular}

Table 3.3: Results of compaction test for sample C (whole sample)

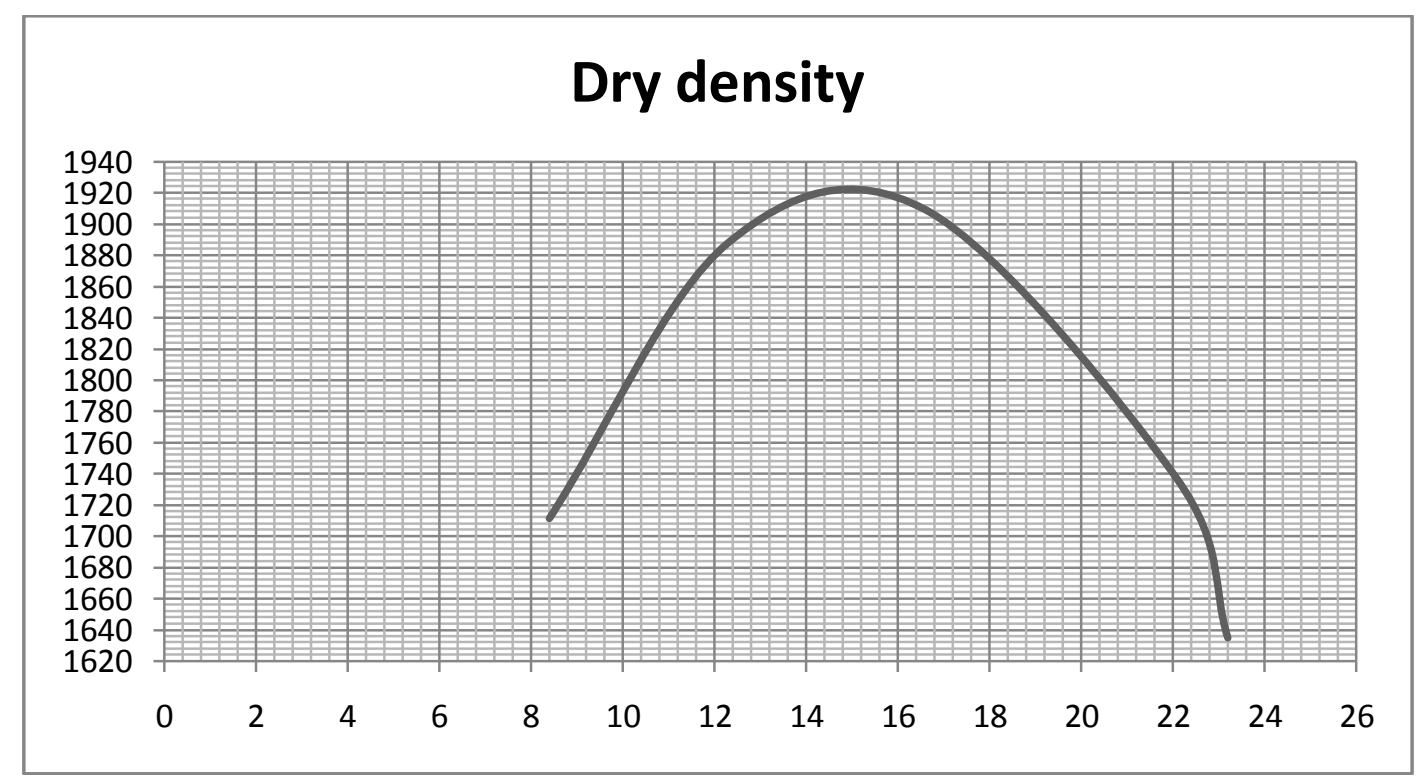

Fig 3.3: Compaction curve for sample C (Whole Sample) 
Each of the sample were sieve were sieved through sieve No. $4(4.75 \mathrm{~mm})$. The soil particle finer then the sieve were used for compaction test and the result and compaction curve were shown in table 3.4-3.6 and fig 3.4-3.6 respectively for each of the samples

\subsection{Sample Passing Through 4.75mm Sieve (method 2)}

SAMPLE A

\begin{tabular}{|l|l|l|l|}
\hline Weight of wet soil & Bulk density $\left(\mathrm{kg} / \mathrm{m}^{3}\right)$ & Moisture content $(\%)$ & Dry density $\left(\mathrm{kg} / \mathrm{m}^{3}\right)$ \\
\hline 1.70 & 1700 & 4.0 & 1634.6 \\
\hline 1.85 & 1850 & 7.5 & 1720.9 \\
\hline 2.00 & 2000 & 11.3 & 1796.9 \\
\hline 1.90 & 1900 & 15.2 & 1649.3 \\
\hline 1.85 & 1850 & 19.4 & 1594.4 \\
\hline
\end{tabular}

Table 3.4: Result of compaction test for sample A finer than sieve No. 4

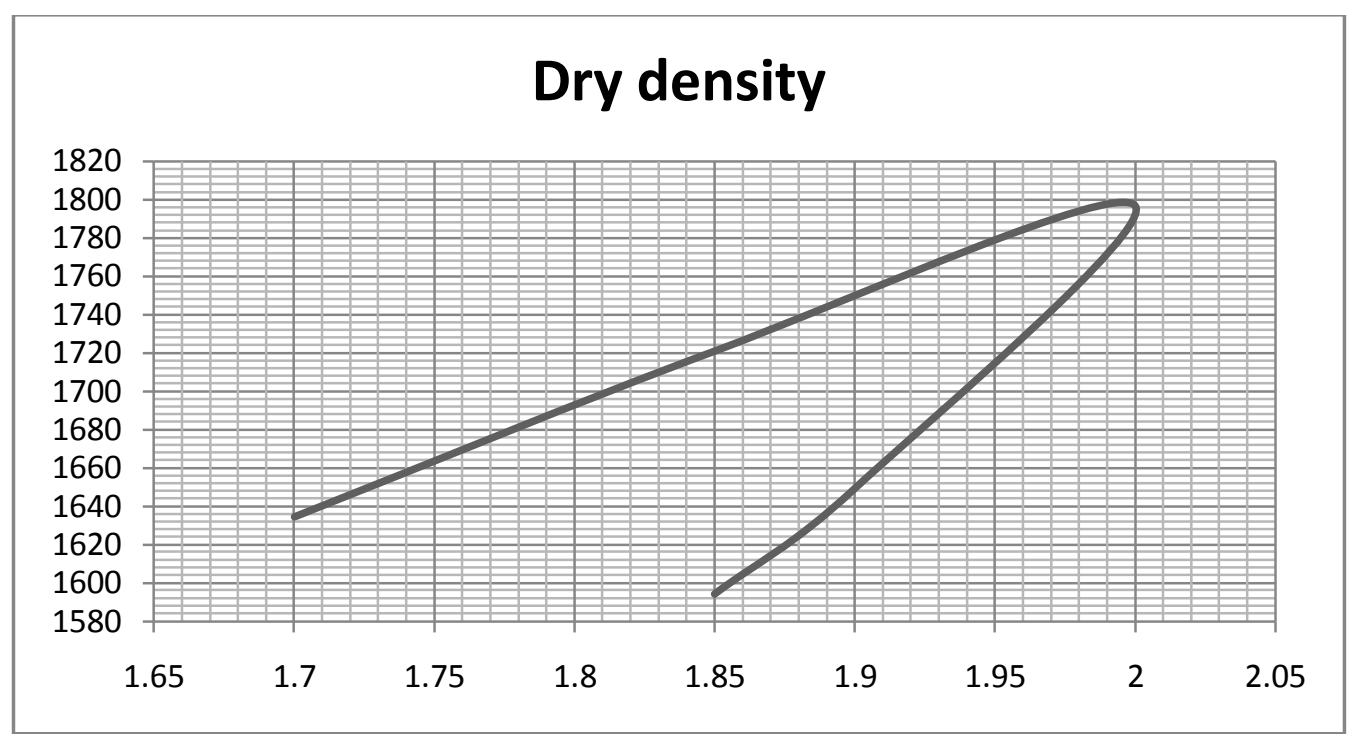

Fig 3.4: Compaction curve for sample $\mathrm{C}$ finer than sieve No 4 .

\begin{tabular}{|c|c|c|c|}
\hline Weight of wet soil & Bulk density $\left(\mathrm{kg} / \mathrm{m}^{3}\right)$ & Moisture content (\%) & Dry density $\left(\mathrm{kg} / \mathrm{m}^{3}\right)$ \\
\hline 1.30 & 1300 & 5.7 & 1229.9 \\
\hline 1.50 & 1500 & 8.8 & 1378.7 \\
\hline 1.95 & 1950 & 12.4 & 1734.9 \\
\hline 1.90 & 1900 & 16.7 & 1628.1 \\
\hline 1.80 & 1800 & 19.9 & 1501.3 \\
\hline
\end{tabular}

Table: 3.5 Results of compaction test f sample B finer than No. 4 sieve

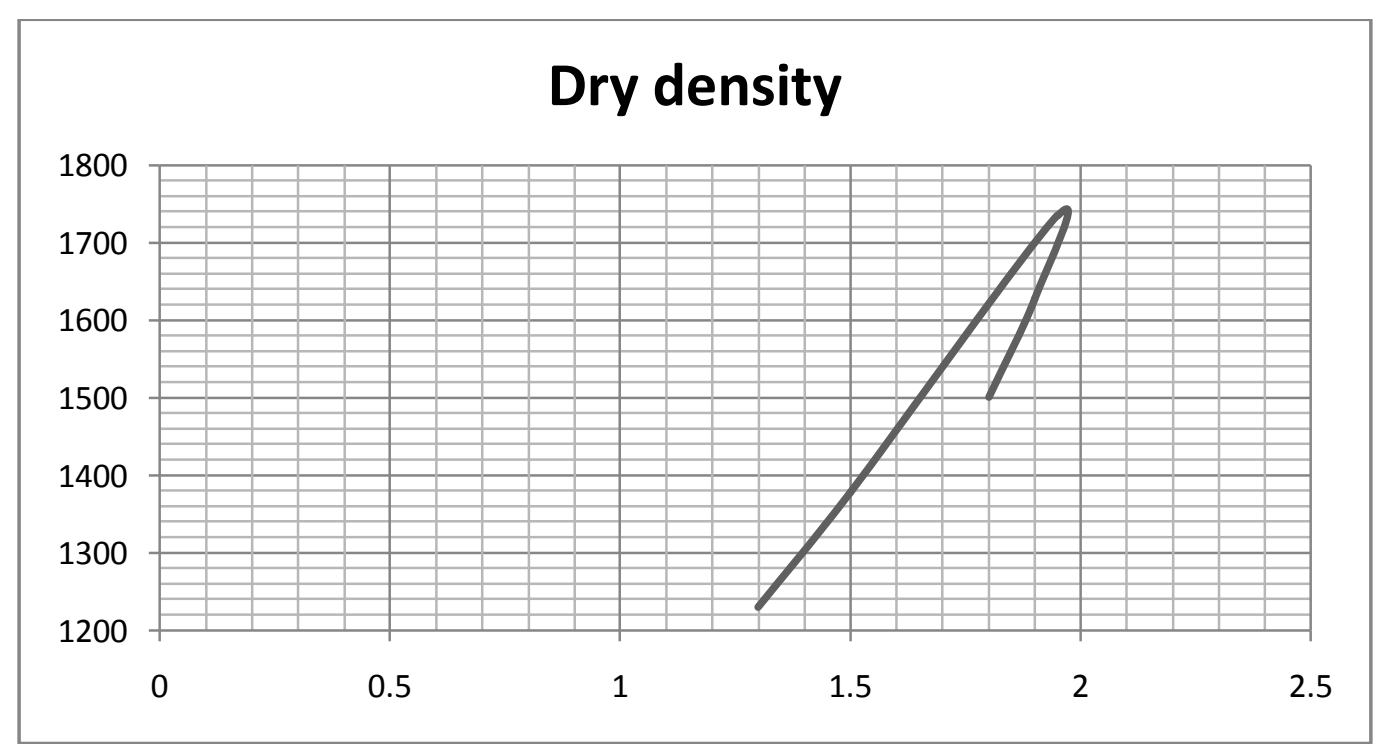

Fig 3.5: Compaction curve for ample finer than No. 4 sieve 


SAMPLE C
\begin{tabular}{|l|l|l|l|}
\hline Weight of wet soil & Bulk density $\left(\mathrm{kg} / \mathrm{m}^{3}\right)$ & Moisture content $(\%)$ & Dry density $\left(\mathrm{kg} / \mathrm{m}^{3}\right)$ \\
\hline 1.48 & 1480 & 4.0 & 1423.1 \\
\hline 1.58 & 1580 & 8.3 & 1458.9 \\
\hline 1.83 & 1830 & 11.0 & 1648.6 \\
\hline 1.88 & 1880 & 15.9 & 1622.1 \\
\hline 1.78 & 1780 & 18.3 & 1504.6 \\
\hline
\end{tabular}

Table 3.6: Results of compaction test for sample $\mathrm{C}$ finer than No. 4 sieve.

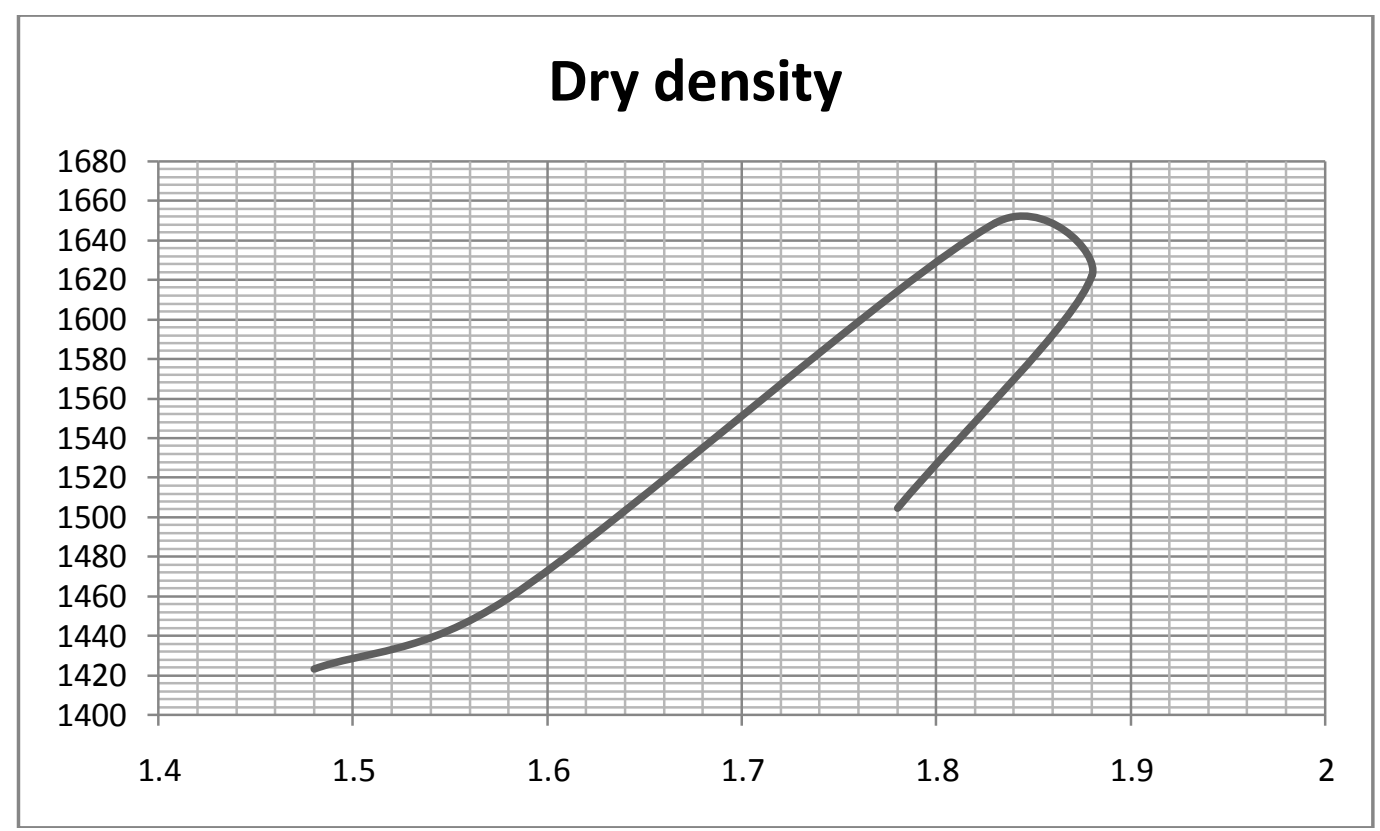

Fig 3.6: Compaction curve for sample finer than No. 4 sieve.

\subsection{Result summary}

The results for each of the test were summarized in tables 3.7-3.9

SAMPLE A

\begin{tabular}{|l|l|l|}
\hline & Whole sample & Passing through sieve No. 4 \\
\hline Max dry density & 1918 & 1800 \\
\hline optimum moisture content & 12.1 & 11.0 \\
\hline
\end{tabular}

Table 3.7: Result and summary for sample A

SAMPLE B

\begin{tabular}{|l|l|l|}
\hline & Shole sample & Passing through sieve No. 4 \\
\hline Max dry density & 1862 & 1745 \\
\hline optimum moisture content & 12.8 & 13.0 \\
\hline
\end{tabular}

Table 3.8: Result summary for sample B

SAMPLE C

\begin{tabular}{|l|l|l|}
\hline & Whole sample & Passing through sieve No. 4 \\
\hline Max dry density & 1924 & 1660 \\
\hline optimum moisture content & 14.5 & 14.5 \\
\hline
\end{tabular}

Table 3.9: Result summary for sample C

3.4 Rock correction using equation (method 3).

Corrections for each of the samples were calculated using equation 2.1 and the following results were obtained after due conversion form English unit to S.I unit

The results of rock correction are as follows

Sample A; Maximum dry density $=2055 \mathrm{Kg} / \mathrm{m}^{3}$

Sample B; Maximum dry density $=1944 \mathrm{~kg} / \mathrm{m}^{3}$

Sample C; Maximum dry density $=1772 \mathrm{~kg} / \mathrm{m}^{3}$

3.5 Comparison of the three methods

Each of the methods were compared for the three samples as shown in table 3.10-3.12 


\section{SAMPLE A}

\begin{tabular}{|c|c|c|}
\hline Method 1 & Method 2 & Difference $(\%)$ \\
\hline 1918 & 1800 & 6.6 \\
\hline \multicolumn{3}{|c|}{ (a) } \\
\hline 1918 & 2055 & 7.1 \\
\hline \multicolumn{3}{|c|}{ (b) } \\
\hline Method 1 & Method 2 & Difference $(\%)$ \\
\hline
\end{tabular}

(c)

Figure 3.10: comparison of the three methods for sample A

SAMPLE B

\begin{tabular}{|c|c|c|}
\hline Method 1 & Method 2 & Difference (\%) \\
\hline 1862 & 1745 & 6.7 \\
\hline \multicolumn{3}{|c|}{ (a) } \\
\hline Method 1 & Method 2 & Difference (\%) \\
\hline 1862 & 1944 & 4.4 \\
\hline \multicolumn{3}{|c|}{ (b) } \\
\hline Method 1 & Method 2 & Difference (\%) \\
\hline 1745 & 1944 & 11.4 \\
\hline
\end{tabular}

(c)

Figure 3.11: Comparison of the methods for sample B.

SAMPLE C

\begin{tabular}{|c|c|c|}
\hline Method 1 & Method 2 & Difference $(\%)$ \\
\hline 1924 & 1660 & 15.9 \\
\hline \multicolumn{3}{|c|}{ (a) } \\
\hline 1924 & 1772 & 8.6 \\
\hline \multicolumn{3}{|c|}{ (b) } \\
\hline Method 1 & Method 2 & Difference $(\%)$ \\
\hline
\end{tabular}

(c)

Fig 3:12: Comparison of the three method for sample $C$

There are overall increases in maximum dry density in all the samples at which the whole samples were compacted. This is as a result of the higher density of rock size material relative to the smaller particles and reinforcing effect of the rock sized material. Higher values were obtained from the correction equations in samples A and B while the maximum dry density for method 3 for sample $C$ is lower than method 2 probably because material retained on sieve no. 4 is lower in that sample when compared to other samples. The difference in maximum dry density between method 1 and method 2 for both samples A and B are almost the same whereas we have a different case for sample $\mathrm{C}$. This may still be as result of closeness in percentage of particle retained on sieve No 4, in samples A and B. This is supported by the extract from ASTM D4718 below.

"This practice is based on test performed on the soil and soil-rock mixtures in which the position considered oversize is that fraction of the material retained on the No. 4 sieve based on these tests, this practice is applicable to soils and soil-rock mixtures in which up to $40 \%$ of the material is retained on the No. 4 sieve. The practice is considered valid when the oversize fraction is portion retained on some other sieve, such as the $3 / 4$ inch sieve, but the limiting percentage of the oversized particles for which the correction is valid may be lower. However, the practice is considered valid for material, having up to $30 \%$ oversize particles when the oversize fraction is that fraction in that portion retained on the 3/4- inch sieve [ASTMD4718-87(2007)].

I recommend that the consultants and contractors should use the average value of maximum dry densities obtained using different methods that suits the type of soil and its constituent's material. I believe that this will give an average value that would serve a standard instead of depending on one particular method. Since there are no consistent differences in maximum dry density, using the average values of suitable method of correction will take care of error in each method.

This goes further to explain the reason why the calculation for rock correction in sample $\mathrm{C}$ with $17 \%$ retained on sieve No. 4 is below the dry density obtained in the compaction of the whole sample unlike in the other samples with values above $30 \%$ retained on sieve no. 4 , proving. Further that the correction works well in a sample with at least $30 \%$ retained on sieve No 4 . 


\section{Reference}

[1]. Braja M. Das (2005) “fundamentals of Geotechnical Engineering” 2 nd edn, Ontario.

[2]. Donaghe, R. T and Townsend, F. C (1976) "scaling and replacement effect on compaction characteristics of earth-rock mixtures" soil specimen preparation for laboratory testing (ASTM STP 599) Am. Soc. For testing and material Philadelphia Ra. 348 -377.

[3]. Hoston SL and Waish K. D. (1993) "comparison of rock correction methods for compaction of clayey soils" Journal of the Geotechnical Engineering 119(4) pg763-778

[4]. Procedure for performing laboratory compaction of soils containing gravel (1990). Method USBR 5515-89, US Dept of the interior, Bureau of reclamation. Denver, Colo.

[5]. "Soil and rock, building stones; geotextiles" (1989). ASTM Standard vol. 408 ASTM, Philadelphia, Pa, 871 -873

[6]. Standard specifications for tr4ansportation materials and methods of sampling and testing part II (1982) Am. Assoc. of state highway and transportation officials Washington, D. C Jul.

[7]. ASTM D4718-87(2007) standard practice for correction of unit weight and water content for soil containing oversize particle 